\title{
Tarping Cover Crops Facilitates Organic No-till Cabbage Production and Suppresses Weeds
}

\author{
Natalie P. Lounsbury
}

Department of Natural Resources and the Environment, University of New Hampshire, 56 College Road, Durham, NH 03824; and River Rise Farm, Turner, ME 04282

Bonnie B. Lounsbury
River Rise Farm, Turner, ME 04282

\section{Nicholas D. Warren and Richard G. Smith \\ Department of Natural Resources and the Environment, University of New Hampshire, 56 College Road, Durham, NH 03824}

Additional index words. occultation, plastic mulch, soil conservation, soil moisture, weed ecology

\begin{abstract}
Small-scale vegetable farmers are interested in cover crops and reduced tillage, but scale-appropriate technology and equipment are necessary to expand these practices to the growing segment of small farms. We sought to determine the efficacy of tarps, an increasingly popular tool on small farms, to end overwintering cover crops and provide weed suppression for subsequent no-till cabbage production. In three fields over two seasons in Maine, we grew a winter rye (Secale cereale $\mathbf{L}$.) and hairy vetch (Vicia villosa $\mathbf{L}$.) cover crop, which we managed by a factorial combination of tillage (no-till, till) and tarping (tarp, no-tarp) in June, followed by a transplanted cabbage crop (Brassica oleracea $\mathrm{L}$. var. Capitata) in July. Within each treatment, subplots were either weeded by hand or left unweeded. Cover crop biomass ranged from 2.8 to $4.5 \mathrm{Mg} \cdot \mathrm{ha}^{-1}$. Mean cabbage weights in the novel no-till system (no-till/tarp) were greater than (year 1) or equal to (year 2) those in tillage-based systems (till/no-tarp and till/tarp). In year 1, the mean cabbage weight in weeded subplots was $48 \%$ greater in no-till/tarp than in till/no-tarp systems. In unweeded subplots, this difference was $270 \%$, highlighting the efficacy of the no-till/tarp system to reduce the impact of weeds. In year 2 , weed biomass was higher with all treatments than it was in year 1, and unweeded subplots failed to produce marketable heads (i.e., $>300 \mathrm{~g}$ ). The mean cabbage weight in weeded subplots was equal among no-till/tarp, till/tarp, and till/no-tarp systems. Tarping had a strong effect on weed biomass and weed community composition measured at the time of cabbage harvest in unweeded subplots. In year 1, weed biomass at the time of cabbage harvest with tarp treatments was less than half that with no-tarp treatments. Tarps effectively facilitated the cover crop mulch-based no-till system. We propose that this system is an adaptive strategy for farmers affected by climate change. However, both cover crop production and tarping shorten the growing season. We discuss tradeoffs and opportunity costs using the metric of growing degree days.
\end{abstract}

Reusable plastic tarps are increasingly common for small-scale organic farmers who want to manage weeds and facilitate reduced-

Received for publication 19 Nov. 2021. Accepted for publication $25 \mathrm{Jan} .2022$

Published online 3 March 2022.

We acknowledge Margo Clark, Liza DeGenring, Michael Ray, Adrian Wadsworth, and Joshua Wagner for field and laboratory assistance.

Partial funding was provided by the New Hampshire Agricultural Experiment Station. This is Scientific Contribution Number 2925. This was supported by the USDA National Institute of Food and Agriculture HATCH Project 100682, USDA NIFA SARE Project LNE18-371, USDA NIFA OREI project 2016-25-8468.

N.P.L. is the corresponding author. E-mail: Natalie.Lounsbury@unh.edu.

This is an open access article distributed under the CC BY-NC-ND license (https://creativecommons. org/licenses/by-nc-nd/4.0/). tillage vegetable production. The use of tarps has been popularized by farming and market gardening books (Fortier and Bilodeau, 2014; Mays, 2020; Mefferd, 2019); however, it has received little attention from researchers (Birthisel and Gallandt, 2019; Lounsbury et al., 2020; Rylander et al., 2020). Many of the farmers featured in these publications apply large amounts of compost (e.g., resulting in mulch depths of 3-10 cm) to bury weed seeds and then deploy tarps between cash crop growing periods to manage weeds and crop residue. This strategy can be effective, but it is limited by the amount of high-quality compost available and has the potential to contribute to nutrient pollution, especially when manure-based compost is used (Small et al., 2019). In states where nutrient management plans are mandatory and phosphorus applications are restricted, this farming system may encounter regulatory constraints (Coale et al., 2002). Alternatives to large amounts of compost are necessary to facilitate more widespread adoption of reducedtillage practices by small-scale farms.

In situ mulch from cover crops is an alternative to compost for weed suppression. Previous efforts to develop reduced tillage systems based on cover crop mulch have had variable results and limited adoption (Brainard et al., 2013; Halde et al., 2017). Incomplete cover crop termination, inadequate weed control from low cover crop biomass, and reduced vegetable yields have hampered progress in these systems (Leavitt et al., 2011; Mochizuki et al., 2007). These issues are especially challenging in northern latitudes, where cover crop biomass production is typically lower and growing seasons are short (Halde et al., 2017). Furthermore, small-scale farmers encounter equipment constraints and do not typically have the tools required for managing high-biomass cover crops (Kornecki and Reyes, 2020; Lowry and Brainard, 2019; O'Connell et al., 2015).

Integrating tarps with cover crops may overcome some of the barriers that previously limited the adoption of cover crop mulch-based systems (Lounsbury et al., 2020). This would improve the sustainability of tarping practices that farmers are already using (i.e., with compost or bare soil). In addition to weed suppression, cover crops provide many benefits, including erosion prevention, improved water infiltration, organic matter contributions, yearround living roots, nutrient capture, and nitrogen $(\mathrm{N})$ fixation (from legumes) (Blanco-Canqui et al., 2015). Because mulch can modulate soil temperature and moisture, maintaining surface mulch is a critical adaptive strategy because many regions experience drier, hotter summers because of climate change (Hayhoe et al., 2007; Kaye and Quemada, 2017).

We sought to investigate the potential of reusable tarps to end overwintering cover crops and facilitate organic no-till cabbage production. Our objectives were to quantify the effects of tillage and tarping on cabbage weight with and without additional weed management and to determine how tillage and tarping affect weed biomass, community composition, and diversity. We conducted field experiments over 2 years in three fields in central Maine. To shed light on the possible mechanisms for observed effects, we quantified cover crop biomass in all three fields and monitored soil moisture and temperature in one field.

\section{Materials and Methods}

Experiment site

We conducted field experiments in 2016-17 (year 1) and 2017-18 (year 2) at a farm according to approved organic practices in Turner, ME (lat. $44^{\circ} 19^{\prime} 27^{\prime \prime} \mathrm{N}$, long. $\left.70^{\circ} 11^{\prime} 22^{\prime \prime} \mathrm{W}\right)$. In year 1 , we conducted the same experiment in two fields with different soil characteristics and weed communities. The Road field is mapped as Merrimac fine sandy loam (sandy, mixed, mesic Typic Dystrudept). The River field is mapped as a Ninigret fine sandy loam (coarse-loamy over 
sandy or sandy-skeletal, mixed, active, mesic Aquic Dystrudepts); however, the absence of redoximorphic features above $1 \mathrm{~m}$ indicate it is well-drained or excessively well-drained and is more likely Agawam fine sandy loam (coarse-loamy over sandy or sandy-skeletal, mixed, active, mesic Typic Dystrudepts). In year 2, we conducted the experiment on an adjacent section of the River field. Both fields had a history of poultry litter application resulting in soil pH levels of 7.1 and 6.9 at the Road and River fields, respectively, and phosphorus and calcium soil test values were considered above optimum by the University of Maine Soil Testing Laboratory. Other macronutrients were considered low-medium. Soil organic matter rates were $4.1 \%$ and $2.8 \%$ at the Road and River fields, respectively. Both fields had a history of vegetable production with tillage and cover crops.

\section{Treatment structure and experimental design}

The treatment structure was a $2 \times 2 \times 2$ factorial with tillage (no-till vs. till), tarp (no-tarp vs. tarp), and weed management (unweeded vs. weeded) as the factors. Main plots were the four tillage $\times$ tarp combinations (no-till/tarp; no-till/no-tarp; till/tarp; till/ no-tarp) organized in a randomized complete block design. Weed management was imposed as a split plot within these treatments. In year 1, each field had four blocks; in year 2 , the field had five blocks. The main plots were $12 \times 3 \mathrm{~m}$, and the subplots were $6 \times$ $3 \mathrm{~m}$. The factorial treatment structure allowed us to look for main effects and interactions among tillage, tarping, and weeding. Additional details about how these treatments were managed is included in the field activities section.

\section{Weather data}

Weather data were downloaded from weather station USC00178817 (Turner, ME). Growing degree days (GDD) were calculated using the following equation:

$$
\mathrm{GDD}=\left(\mathrm{T}_{\max }+\mathrm{T}_{\text {min }}\right) / 2-\mathrm{T}_{\text {base }}
$$

where $T_{\max }$ is the maximum daily temperature, $\mathrm{T}_{\min }$ is the minimum daily temperature, and $\mathrm{T}_{\text {base }}$ is $4{ }^{\circ} \mathrm{C}$; mean temperatures below $\mathrm{T}_{\text {base }}$ were considered zero. Cumulative GDD for the cover crop growing seasons were calculated as the summation of daily GDD starting on the day of cover crop seeding until the cover crop biomass was harvested (Table 1).

Table 1. Field activities of cover crop, tarp, and cabbage production sequence in Turner, ME, in 2016-17 (year 1) and 2017-18 (year 2).

\begin{tabular}{lccc}
\hline & Road Yr 1 & River Yr 1 & River Yr 2 \\
\hline Cover crop seeding & 25 Sept. & 25 Sept. & 25 Sept. \\
Cover crop biomass harvest & 3 June & 4 June & 3 June \\
Rototill & 4 June & 4 June & 5 June \\
Apply tarps & 5 June & 8 June & 5 June \\
Remove tarps and transplant cabbage & 4-5 July & $5-6$ July & $1-6$ July \\
Fertilize cabbage & 1 Aug. & 19 July & 10 July \\
Weeded (first weeding) & 29 July & 31 July & 19 July \\
Harvest cabbage & 21 Aug. & 31 Aug. & 1 Sept. \\
Harvest weeds in unweeded subplots & 23 Aug. & 1 Sept. & 7 Sept. \\
\hline
\end{tabular}

Cumulative GDD for the tarping period and cabbage growth period were similarly calculated from the day of tarp application until the day of tarp removal, and from the day of cabbage transplanting until the day of cabbage harvest. The common base temperature for winter rye and hairy vetch is $4{ }^{\circ} \mathrm{C}$ (Mirsky et al., 2009; Teasdale et al., 2004). There are few data regarding the appropriate base temperature for cabbage. We used this base temperature for all periods of the cropping sequence to allow for comparisons with a common unit.

\section{Field activities}

Dates for field activities are presented in Table 1. Fields were rototilled before seeding cover crops. In year 1, cereal rye (Secale cereale L., VNS) and hairy vetch (Vicia villosa Roth, VNS), both from Johnny's Selected Seeds (Winslow, ME), were mixed and seeded in the fall at rates of 50 and $13 \mathrm{~kg} \cdot \mathrm{ha}^{-1}$, respectively, using two passes of a vacuum seeder (MaterMacc, S. Vito al Tagliamento, Italy) to create rows $15 \mathrm{~cm}$ apart. In year 2, 'Aroostook' cereal rye (Albert Lea Seeds, Albert Lea, MN) was seeded with VNS hairy vetch (Johnny's Selected Seeds) at rates of 145 and $34 \mathrm{~kg} \cdot \mathrm{ha}^{-1}$, respectively, using a Brillion $3 \mathrm{~m}$ drop seeder (Landoll, Marysville, KS). Although both seeding rates were within the recommended range, the rates in year 2 were higher to account for broadcast seeding. Vetch was inoculated with Rhizobium leguminosarum biovar. viceae (Verdesian LifeSciences, Cary, NC) both years before seeding.

In the subsequent June, when rye was in anthesis and vetch had not yet begun to flower, we rolled cover crops in the no-till/ tarp treatment with a disengaged rototiller before applying tarps to lay them flat without creating stubble that could puncture the tarps. We mowed cover crops in all other treatments with a sickle bar mower. Tilled plots were rototilled to $\approx 12 \mathrm{~cm}$. In the tarped treatments, tarps were new, 0.10-mm (4-mil), lowdensity polyethylene black film that were kept in place with $15-\mathrm{cm}$ sod staples placed every 1 $\mathrm{m}$ along the edges. To control actively growing weeds in the no-tarp treatments, additional weed management was applied before transplanting cabbage. The till/no-tarp treatment was managed in accordance with a stale seedbed practice (Boyd et al., 2006) and was lightly hoed with a stirrup hoe (Johnny's Selected Seeds). The no-till/no-tarp treatment was managed by mowing with a gas-powered,

HortScience Vol. 57(4) April 2022 walk-behind deck lawnmower at $10 \mathrm{~cm}$ above the soil surface; this did not entirely end weeds or cover crop regrowth; however, this represents the limited nonchemical options (other than tarps) allowable under organic standards.

We transplanted cabbage (Brassica oleracea L. var. Capitata 'Tiara'; Johnny's Selected Seeds) in all treatments in early July. This cultivar is a mini cabbage for high-density plantings and has a typical head weight of $\approx 450$ to $900 \mathrm{~g}$. Holes were established with a container dibble bar with a $15-\mathrm{cm} \times 3.8-\mathrm{cm}$ dibble point (Forestry Suppliers Inc., Jackson, MS). Three rows of cabbages were planted per plot with $30-\mathrm{cm}$ in-row spacing and $46-\mathrm{cm}$ betweenrow spacing. With a typical spacing of $0.9 \mathrm{~m}$ between beds, this is equivalent to a population of 53,930 cabbages/ha.

Because of extremely dry conditions, we applied $\approx 3 \mathrm{~cm}$ of irrigation immediately after transplanting cabbage in year 2 using overhead sprinklers (Rain Bird Corporation, Azusa, CA). No other irrigation was applied. We applied fertilizer approved for organic production $(8.7 \mathrm{~N}-1.1 \mathrm{P}-1.8 \mathrm{~K}$; Kreher Family Farms, Clarence, NY) next to each plant without incorporation at a rate of $135 \mathrm{~kg} \cdot \mathrm{ha}^{-1}$ $\mathrm{N}$ in the River field (both years) and 68 $\mathrm{kg} \cdot \mathrm{ha}^{-1} \mathrm{~N}$ in the Road field because of delayed application and higher soil organic matter levels.

During the cabbage production period, we removed weeds in the weeded subplots only. We pulled large weeds by hand and used a hand hoe to uproot small weeds at the soil surface (Johnny's Selected Seeds). We attempted to disturb the mulch in the no-till treatments as little as possible. To control imported cabbage worms (Pieris rapae L.), we sprayed 'Entrust' (Dow Agrosciences, Indianapolis, IN) with active ingredient Spinosad at the label rate on 10 Aug. 2017 and on 24 Aug. 2018.

\section{Cover crop biomass}

To determine cover crop biomass and the rye:vetch ratio, we harvested two $0.25-\mathrm{m}^{2}$ quadrats from each main plot just before termination by cutting stems originating within the quadrat. Rye and vetch were separated in the field and dried at $65^{\circ} \mathrm{C}$ for more than 48 $\mathrm{h}$; then, they were weighed.

\section{Cabbage head weights}

Ten individual cabbage heads were harvested from a randomly selected section of each subplot (weeded or unweeded) from all three rows. In some plots, it was not possible to obtain all 10 heads from immediately adjacent heads because of significant porcupine (Erethizon dorsatum L.) herbivory. The herbivory occurred very close to the harvest date, and we do not believe this affected competition between cabbage heads. The cabbages were harvested from the Road field in year 1 slightly earlier than anticipated to avoid additional porcupine damage. Before measurement, outer leaves were removed and individual marketable heads were weighed fresh. 


\section{Soil moisture and temperature}

In year 2, we measured hourly soil moisture and temperature at a soil depth of $15 \mathrm{~cm}$ in the weeded no-till/tarp and till/no-tarp treatments of three blocks using GS3 and 5TE soil temperature and capacitance moisture sensors (Meter Environment, Pullman, WA). This depth was below the depth of tillage $(12 \mathrm{~cm})$ so that volumetric water content could be compared between till and no-till treatments without any confounding effects of bulk density.

\section{Weed biomass and community structure}

In year 1, we harvested weeds within a few days after cabbage harvest from a 1.2- $\times$ $1.8-\mathrm{m}$ quadrat to cover all three rows where cabbages had been growing. In year 2 , the weed biomass was substantially greater, and we harvested two $0.25-\mathrm{m}^{2}$ quadrats from each unweeded subplot after cabbage harvest. We separated weeds by species, dried them at $65^{\circ} \mathrm{C}$ for more than $48 \mathrm{~h}$, and weighed them.

\section{Analyses}

All analyses were performed within the $\mathrm{R}$ environment ( $\mathrm{R}$ Core Team, 2020). We analyzed the cabbage mean head weight using a linear mixed model with a three-way analysis of variance (ANOVA) with the "lme4" package (Bates et al., 2015). Tillage, tarp, and weed management were fixed effects and block was a random effect. The block was nested within the field in year 1. Field was included as a fixed effect to determine if there was a field effect or interactions. If field was not significant, then it was not included in the model. Weed biomass data from the unweeded subplots were analyzed using a two-way ANOVA with tillage and tarp as fixed effects. Because of an effect of field in year 1, fields were separated and analyzed individually. Cabbage head weight and weed biomass data were checked for assumptions of ANOVA, and all data met both normality and homoscedasticity assumptions except the cabbage weight from year 2 , which had nonnormal residuals. Because the homoscedasticity assumption was met, the data were analyzed without transformation (Schmider et al., 2010). When there was a significant interaction between factors, we present simple effect means. Means contrasts were performed with the "emmeans" package (Length, 2020) using Tukey's honestly significant difference with $\alpha=0.05$.

To determine if there were differences in weed community composition and diversity resulting from tarp and tillage treatments, we calculated the Shannon diversity index and performed a permutational multivariate ANOVA (PerMANOVA) on $\log (\mathrm{x}+1)$ transformed biomass of species (Anderson, 2001). For both analyses, we used the "vegan" package (Oksanen et al., 2015). PerMANOVA was performed with the Bray-Curtis distance matrix using the "adonis" function. For visualization purposes, community data are presented as relative abundance of species representing $>1 \%$ of the total weed biomass for River years 1 and 2 and representing $>5 \%$ of the total weed biomass in the
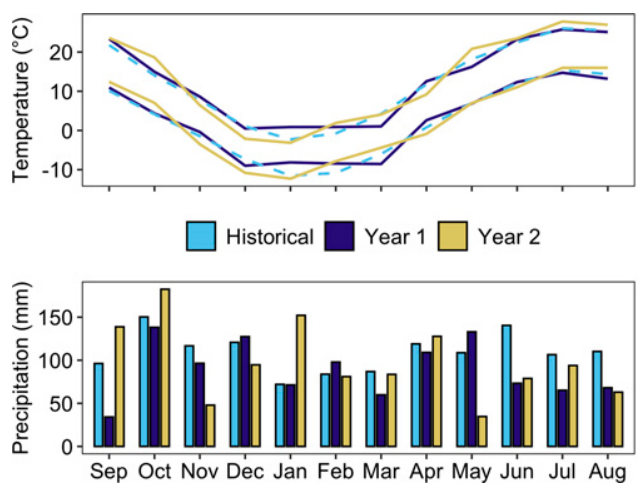

Fig. 1. Monthly maximum and minimum air temperatures (top) and monthly precipitation (bottom) in Turner, ME. Historical data are from 2002-2016. Experiment years were 2016-17 (year 1) and 2017-18 (year 2).

Road field. All figures were created with the $\mathrm{R}$ "ggplot2" package (Wickham, 2016).

\section{Results}

\section{Weather}

The most striking difference between years was that precipitation in May was $22 \%$ $(+24 \mathrm{~mm})$ above average in year 1 and $69 \%$ $(-75 \mathrm{~mm})$ below average in year 2 (Fig. 1). Both years had below average precipitation for the subsequent months of June, July, and August. Temperatures were warmer in year 2 than year 1 , leading to greater cumulative GDD for the periods of cover crop growth, tarping, and cabbage growth (Table 2).

\section{Cover crop biomass}

Cover crop biomass at the time of termination ranged from 2.8 to $4.5 \mathrm{Mg} \cdot \mathrm{ha}^{-1}$ and was dominated by rye in all fields (Table 3 ). The proportion of vetch in all fields was low, comprising less than $20 \%$ of the total biomass. The River and Road fields in year 1 had different total biomass $(P=0.002)$ and rye:vetch proportion, despite identical seeding methods and weather.

\section{Cabbage head weight}

In both years, individual cabbage heads in the highest-yielding treatments were in the size range specified by the seed company for this cultivar (450-900 g) (Fig. 2). In both years, multiple interactions precluded an analysis of the main effects of tillage, tarping, and weeding (objectives 1 and 2). In year 1 , there was no effect of field on mean cabbage weight, even though there was a $10-d$ and $>130$ GDD difference between cabbage harvest dates. Therefore, cabbage data from the two fields in year 1 were analyzed together.
Treatment effects in year 2 differed from year 1 and were analyzed separately.

Within the weeded subplots, mean cabbage weight in the no-till/tarp treatment was either greater than (year 1) or equal to (year 2) that of all other treatments. The no-till/no-tarp treatment, however, consistently was the lowestyielding treatment, producing cabbages that were not of marketable size (year 1) or were not harvestable (year 2). It should be noted, however, that the weed management practices of no-till/no-tarp (e.g., mowing before cabbage transplanting and subsequent hand weeding) did not keep the plots free of weeds.

The effect of weeding on mean cabbage weight was significant in all treatments in both years; however, the magnitude of the weeding effect was highly variable. In year 1 , the weeding effect was greatest in till/no-tarp, where weeding more than doubled the mean cabbage weight. The effect was much smaller in the tarped treatments. Weeding increased cabbage weight in no-till/tarp, but the mean cabbage weight in the unweeded no-till/tarp was still equal to or greater than that in all other treatments, even weeded ones. The effects of weeding were more pronounced in year 2 , during which cabbage weights in all the unweeded treatments were $<50 \%$ of their weeded counterparts. All of the unweeded treatments had mean cabbage weights $<300$ g. Cabbages in the unweeded no-till/no-tarp treatment did not form heads and could not be harvested.

The effect of weeds on cabbage weight can be further elucidated by the relationship between weed biomass and cabbage weight in the unweeded subplots. Using individual plot data, there was a negative linear correlation between weed biomass and cabbage weight in both years. Differences in weed

Table 2. Cumulative growing degree days for periods of cover crop, tarping, and crop production in Turner, ME, in 2016-17 (year 1) and 2017-18 (year 2)

\begin{tabular}{lccccc}
\hline & $\begin{array}{c}\text { Fall cover } \\
\text { crop growth }\end{array}$ & $\begin{array}{c}\text { Spring cover } \\
\text { crop growth }\end{array}$ & $\begin{array}{c}\text { Total cover } \\
\text { crop growth }\end{array}$ & Tarping period & Cabbage growth \\
\cline { 2 - 6 } & \multicolumn{7}{c}{ Cumulative growing degree days (base 4 ${ }^{\circ}$ C) } \\
\hline River (year 1) & 321 & 469 & 790 & 414 & 892 \\
Road (year 1) & 321 & 461 & 782 & 428 & 758 \\
River (year 2) & 421 & 519 & 940 & 441 & 994 \\
\hline
\end{tabular}


Table 3. Cover crop biomass of winter rye-hairy vetch biculture. Data are presented as means with SD in parentheses. Year 1 had four replications per field and year 2 had five replications per field.

\begin{tabular}{llll}
\hline \multirow{2}{*}{ Field } & $\begin{array}{c}\text { Total } \\
\text { biomass }\end{array}$ & $\begin{array}{c}\text { Rye } \\
\text { biomass }\end{array}$ & $\begin{array}{c}\text { Vetch } \\
\text { biomass }\end{array}$ \\
\cline { 2 - 4 } & & $\mathrm{Mg} \cdot \mathrm{ha}^{-1}$ & \\
\hline
\end{tabular}

\begin{tabular}{lllll}
\hline River (year 1) & $4.5(0.77)$ & $4.1(0.80)$ & $0.44(0.12)$
\end{tabular}

$\begin{array}{lllll}\text { Road (year 1) } & 3.3(0.40) & 2.7(0.53) & 0.64(0.23)\end{array}$

\begin{tabular}{lllll} 
River (year 2) $2.8(0.51)$ & $3.0(0.41)$ & $0.50(0.18)$ \\
\hline
\end{tabular}

biomass accounted for a large fraction of the variability in cabbage weight in year $1 \mathrm{(n}=$ $\left.32, R^{2}=0.56, P<0.0001\right)$, but the relationship was not as strong in year $2\left(\mathrm{n}=15, R^{2}=\right.$ $0.20, P=0.012$ ).

\section{Soil moisture and temperature}

Soil temperature in year 2 throughout the tarping/stale seedbedding period appeared to be higher in the no-till/tarp treatment than in the till/no-tarp treatment (Fig. 3A), but the average $1.5^{\circ} \mathrm{C}$ difference was not significant $(P=0.15)$. During the period of cabbage production, there was no difference in soil temperature $(P=0.66)$ (Fig. 3B). The efficacy of tarps at maintaining moisture by excluding precipitation and limiting evaporation is evident from the relative stability of soil moisture in the no-till/tarp treatment, the daily mean of which had a CV of 0.15 , compared with the fluctuating soil moisture levels in the till/notarp treatment, which had a $\mathrm{CV}$ of 0.33 (Fig. 3C). Soil moisture in the two treatments quickly converged after tarp removal when we irrigated once, and then during subsequent precipitation events (Fig. 3D). Differences in soil moisture content during the cabbage production period were not significant $(P=0.70)$.

\section{Weed biomass and communities}

Tarping consistently reduced weed biomass (Fig. 4, objective 2). This main effect was significant in both fields in year 1 , although the magnitude of the effect varied between the River and Road fields (i.e., there was a field $\times$ tarp interaction), and the two fields are presented separately. The effect of tarping was marginal $(P=0.079)$ in year 2 , during which weed biomass was higher across all treatments than in year 1. Unlike tarping, tillage did not have a consistent effect on weed biomass at the time of cabbage harvest. In the Road field only, tillage had a marginal effect $(P=0.055)$ on reducing weed biomass, but the effect size was less than half that of tarping. There were no tarp $\times$ tillage interactions on weed biomass.

In addition to changes in weed biomass, tarp and tillage treatments led to different weed community compositions (Fig. 5). The PerMANOVA indicated a significant tarp $\times$ tillage $\times$ field effect on weed communities in year 1 $(P=0.004)$. The tarp $\times$ tillage interaction remained significant in the Road field $(P=$ $0.001)$ and the River field $(P=0.011)$. These community effects also manifested in differences in the Shannon diversity index (Table 4). In year 1, diversity was lowest in the no-till/ tarp plots and highest in the no-till/no-tarp plots. In year 2, PerMANOVA indicated a significant effect of $\operatorname{tarp}(P=0.001)$ on weed community composition; however, there were no differences in diversity between treatments. Redroot pigweed (Amaranthus retrofexus L.) and common lambsquarters (Chenopodium album L.) were the only weed species occurring in all three fields at $>1 \%$ biomass, whereas large crabgrass [Digitaria sanguinalis
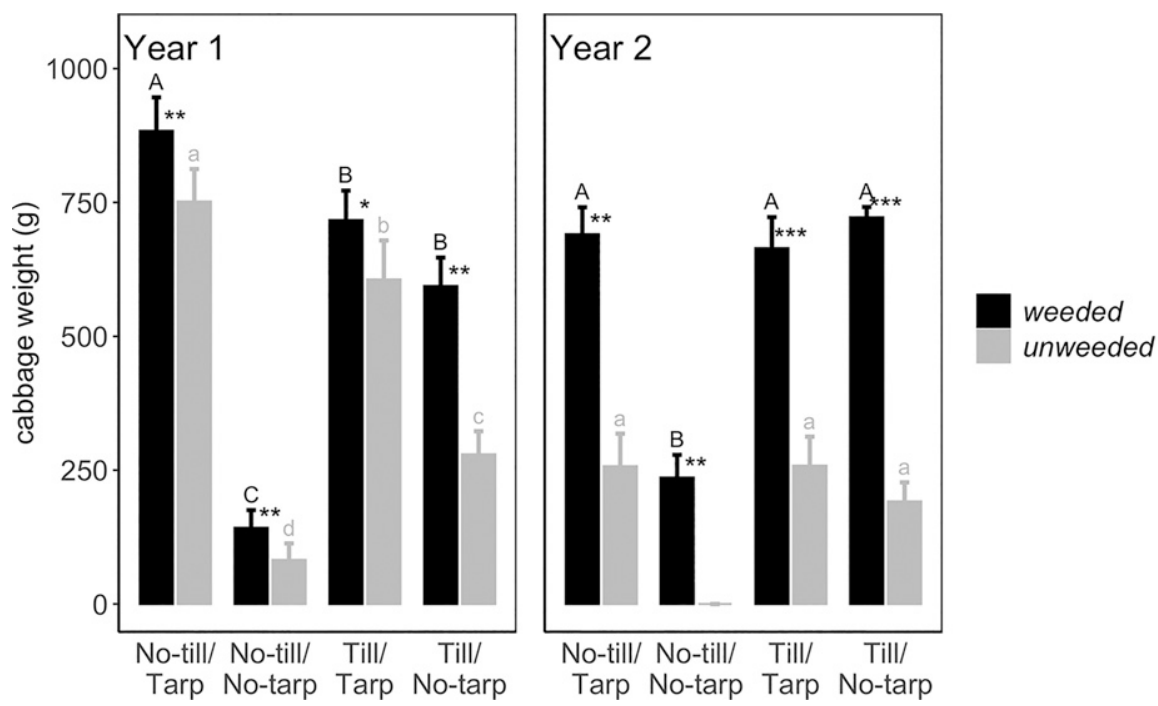

Fig. 2. Cabbage mean head weight from two years in Turner, ME. Year 1 had two fields that were pooled $(n=8)$. Year 2 had one field $(n=5)$. All plots had a winter rye-hairy vetch cover crop before tillage and tarping treatments. Subplots of each tillage-tarp combination were weeded. Error bars indicate the SEM. *Significance between the weeded and unweeded subplots within each tillage-tarp treatment combination. Uppercase letters indicate differences between the weeded treatments within each year. Lowercase letters indicate differences between the unweeded treatments within each year. Means with a common letter are not different.
(L.) Scop.] was common in both years in the River field, especially in year 2.

\section{Discussion}

\section{Cover crop performance}

Cover crop biomass in our experiment was well below the levels required to provide adequate weed suppression via cover crop mulch alone. In southern latitudes, $8 \mathrm{Mg} \cdot \mathrm{ha}^{-1}$ has been suggested as a threshold for cover crop mulch-based systems (Mirsky et al., 2013; Reberg-Horton et al., 2012). Some authors have proposed that lower biomass levels (e.g., 5-6 Mg.ha ${ }^{-1}$ ) may be sufficient in northern latitudes (Wallace et al., 2017), but data are lacking to develop thresholds. Furthermore, weed species vary in their response to cover crop biomass and residue composition (Pittman et al., 2020; Teasdale and Mohler, 2000). The relatively low biomass in our experiment was likely a result of low GDDs as well as extremely low precipitation in May in year 2. Although there is the potential to increase biomass through earlier fall seeding, delayed spring termination, and perhaps higher seeding densities (Boyd et al., 2009; Mirsky et al., 2011), our results highlight the challenges involved in relying on cover crop biomass alone to provide adequate weed suppression in northern latitudes. Our results also highlight the role of edaphic factors in determining cover crop biomass, as evidenced by the difference in biomass between the closely situated Road and River fields in year 1 .

Although we did not measure $\mathrm{N}$ content of cover crops, the low hairy vetch proportion in all fields indicates that the $\mathrm{N}$ contribution was likely low (e.g., $<25 \mathrm{~kg} \cdot \mathrm{ha}^{-1}$ assuming $4 \% \mathrm{~N}$ ). To provide significant $\mathrm{N}$ fertilizer replacement value, alternative management to increase hairy vetch biomass likely will be necessary. Hairy vetch matures later than winter rye and continues to accumulate biomass and fix $\mathrm{N}$ after winter rye has reached peak biomass (Mirsky et al., 2017; Thapa et al., 2018). This suggests that delayed termination in spring may be a strategy worth pursuing to increase the total $\mathrm{N}$ contribution from rye-vetch cover crop mixtures, although subsequent $\mathrm{N}$ mineralization is a function of multiple factors. In regions where $\mathrm{P}$ applications are restricted, higher contributions of biologically fixed $\mathrm{N}$ from legume cover crops is an effective strategy to meet crop $\mathrm{N}$ requirements with minimal external inputs (Ackroyd et al., 2019).

\section{Cabbage weight}

Tillage and tarping. Equal (year 2) and greater (year 1) mean cabbage weights for no-till/tarp compared with the more traditional till/no-tarp (i.e., stale seedbed) show that tillage is not necessary, and sometimes disadvantageous, to produce the highest cabbage yields. Tarps were essential to make no-till viable, as evidenced by dramatic differences in mean cabbage weight between notill/tarp and no-till/no-tarp. Tarps alleviated 

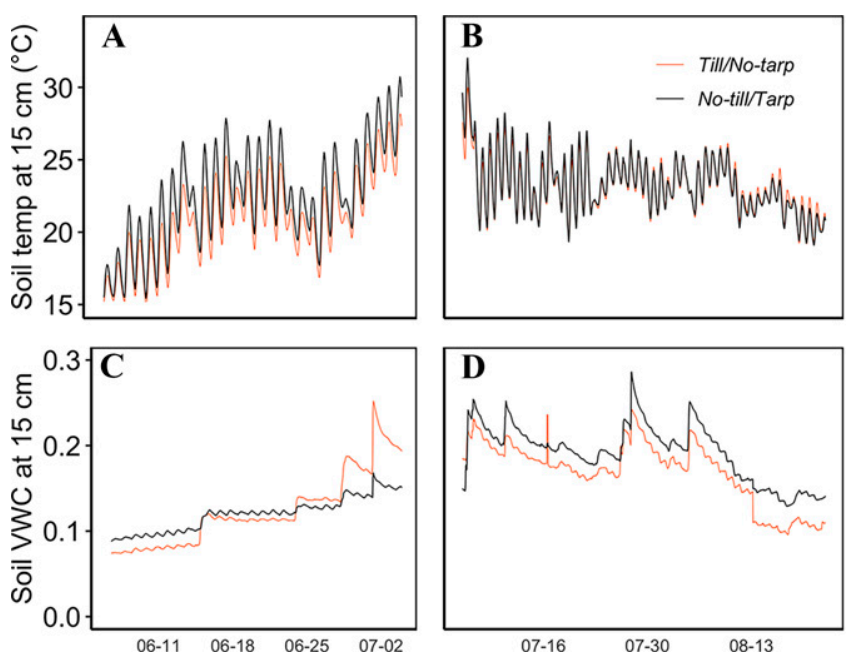

Fig. 3. Soil temperature and volumetric water content (VWC) during the period of tarping/stale seedbedding $(\mathbf{A}, \mathbf{C})$ and cabbage growth $(\mathbf{B}, \mathbf{D})$ in year 2 . The till/no-tarp treatment was a stale seedbed. The tarp was removed for the period of cabbage growth in the no-till/tarp treatment and cover crop residue remained on the soil surface. Lines are the means of three replications. There were no statistically significant differences between treatments.

some of the yield limitations of cabbage growth identified in the previous cover cropbased no-till research by completely ending cover crops and existing weeds at cabbage planting and providing additional weed suppression through the cabbage growing season (Fig. 4). Other yield-limiting factors in previous research, including preemptive competition from cover crops and low $\mathrm{N}$ availability, even when fertilizer in excess of recommended rates has been applied, appear to have not been constraints in the no-till/tarp system (Hefner et al., 2020; Leavitt et al., 2011; Mochizuki et al., 2008).

Tarps can affect soil temperature and moisture dynamics in two key ways that may explain why $\mathrm{N}$ availability appears to have not been a yield-limiting factor in no-till/tarp. Tarps exclude precipitation; therefore, leaching losses when they are in place are minimal. At multiple sites, an accumulation of soil nitrate that increased with tarp duration was observed when tarps were placed over a winterkilled oat (Avena sativa L.) cover crop (Rylander et al., 2020). Additionally, higher temperatures, although not in excess of $30^{\circ} \mathrm{C}$, may lead to greater $\mathrm{N}$ mineralization under tarps if there is sufficient moisture (Cassman and Munns, 1980). However, very little information exists about how tarping affects microbial function, and this speculation needs further study. Despite soil temperature data from year 2 showing that tarped cover crops had equal or perhaps even higher soil temperatures compared with bare soil, it should be noted that other studies with larger quantities of cover crop biomass have observed that large amounts of mulch under tarps can limit tarp-soil contact, thereby reducing soil temperatures in some conditions (Lounsbury et al., 2020).

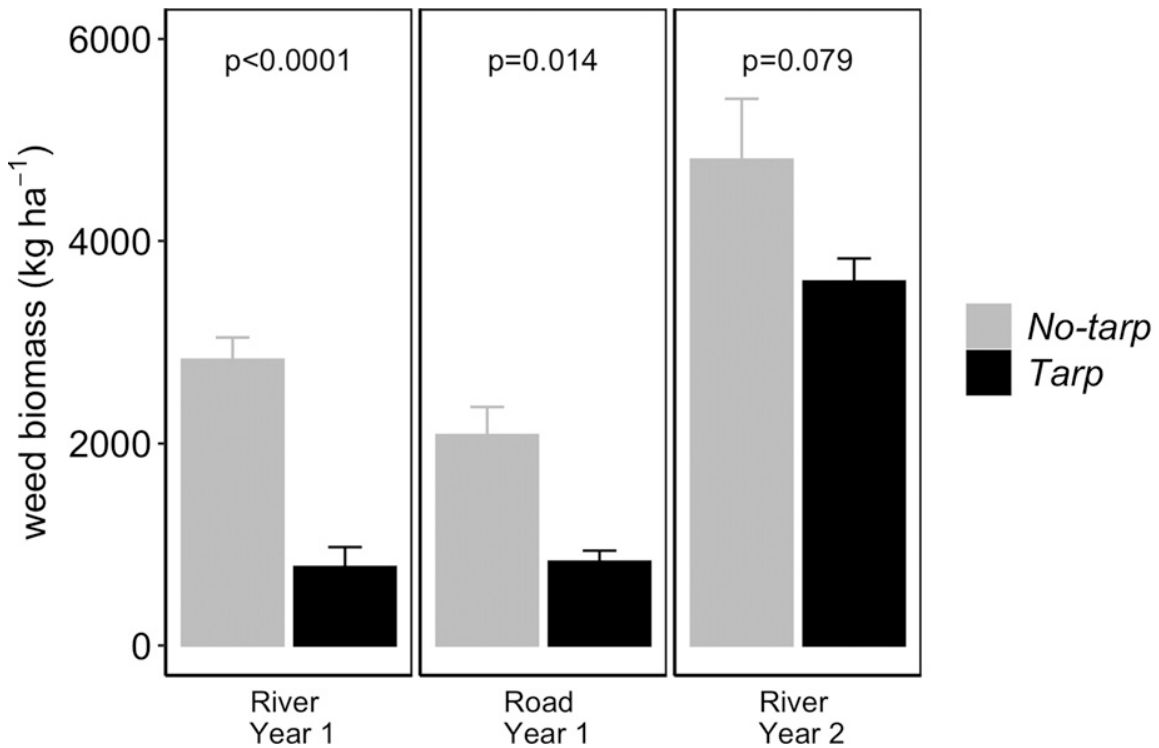

Fig. 4. Weed biomass in unweeded subplots after cabbage harvest. Means of tarp and no-tarp treatments include both no-till and till. $P$ values are presented for each field for the main effect of tarping. Error bars indicate the SEM $(n=8$ for year 1 fields and $n=10$ for year 2 River field).
Perhaps more important than the evidence that no-till/tarp can overcome some of the yield limitations of previous cover crop mulchbased no-till is that no-till/tarp can provide a yield advantage over tilled systems under certain conditions. We speculate that the higher mean cabbage weight of no-till/tarp compared with all other treatments in year 1 was partly a result of moisture conservation from cover crop mulch, although we do not have soil moisture data to support this. Cover crop mulch prevents the loss of moisture under droughty conditions by reducing evaporation (Teasdale and Mohler, 1993). It is possible that higher moisture levels under the cover crop mulch (no-till/tarp) were not observed in year 2 because of lower initial cover crop biomass levels (Table 3). Additionally, differences in precipitation patterns between years 1 and 2 may have contributed to the effects of mulch on mean cabbage weight. Precipitation in the month of July when cabbages had just been transplanted was substantially below average in year 1, but it was close to the norm in year 2 (Fig. 1). In year 1, moisture conservation during this period may have been more important because of lower rainfall to support crop growth. These results highlight that current production systems may not be optimized for a changing climate.

Our decision to not have a bare soil (no cover crop) control made it difficult to assess whether preemptive competition from cover crops limited cabbage yields. We acknowledge that our till/no-tarp practice, although a form of stale-seedbedding, is not "standard." However, mean cabbage weights in the highest-yielding treatments of our experiment were within the mid to upper range specified by the seed company. Furthermore, cabbages were produced within fewer than the $63 \mathrm{~d}$ to maturity specified by the seed company, and in summers that were drier than average. This suggests that the cabbage weights in our treatments were normal, not dramatically reduced, as was the case for Hefner et al. (2020) who observed $68 \%$ to $100 \%$ cabbage yield reductions following roll-crimped cover crops compared with tilled, bare soil controls. The 4-week period of either tarping or stale seedbedding between cover crop termination and cabbage transplanting may have reduced risks of preemptive competition from cover crops.

It should also be noted that inherent and management-induced soil properties have an important role in the success of no-till planted vegetables. Identical management practices can have highly site-specific effects, especially when soil compaction is present (Lounsbury and Weil, 2015). Cabbage and many other vegetables are sensitive to soil compaction and the associated condition of saturated soils (Mochizuki et al., 2007; Wolfe et al., 1995). The soils in this study were not susceptible to these conditions.

Weeds. Tarping was very effective at reducing weed biomass in year 1, likely contributing to the small difference in cabbage mean weight of weeded and unweeded subplots in tarped treatments. In contrast, the large difference between weeded and 


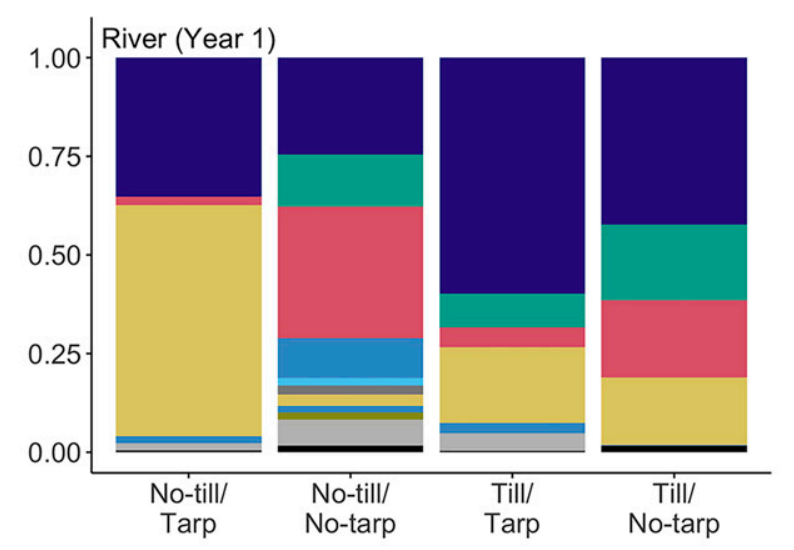

Amaranthus retroflexus $L$.

Chenopodium album $L$

Digitaria sanguinalis (L.) Scop.

Erigeron canadensis $L$

Oenothera biennis $L$.

Phleum pratense $L$.

Portulaca oleracea $L$.

Taraxacum officinale F. H. Wigg.

Trifolium pratense $L$.

Vicia villosa Roth

Other ( $<1 \%$ biomass each)

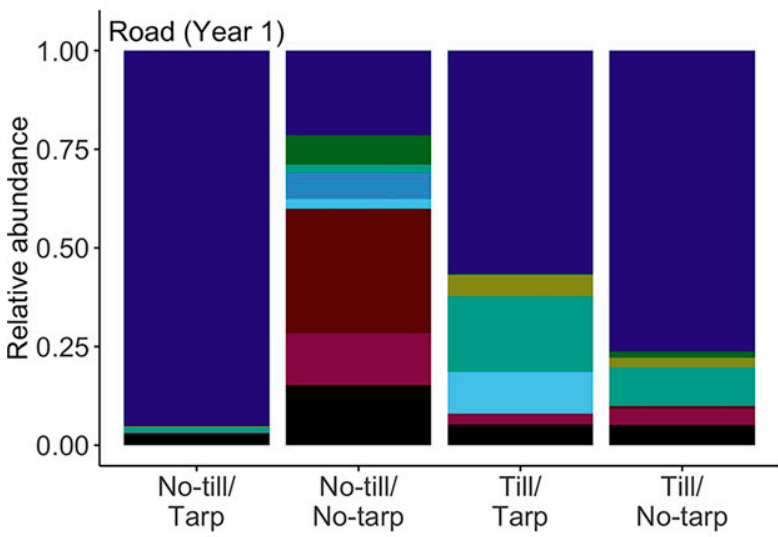

Amaranthus retroflexus $L$

Ambrosia artemisiifolia $L$

Capsella bursa-pastoris (L.) Medik

Chenopodium album $L$.

Erigeron canadensis $L$.

Galinsoga quadriradiata Cav.

Lolium perenne $L$.

Sinapis arvensis $L$.

Other ( $<5 \%$ biomass each)

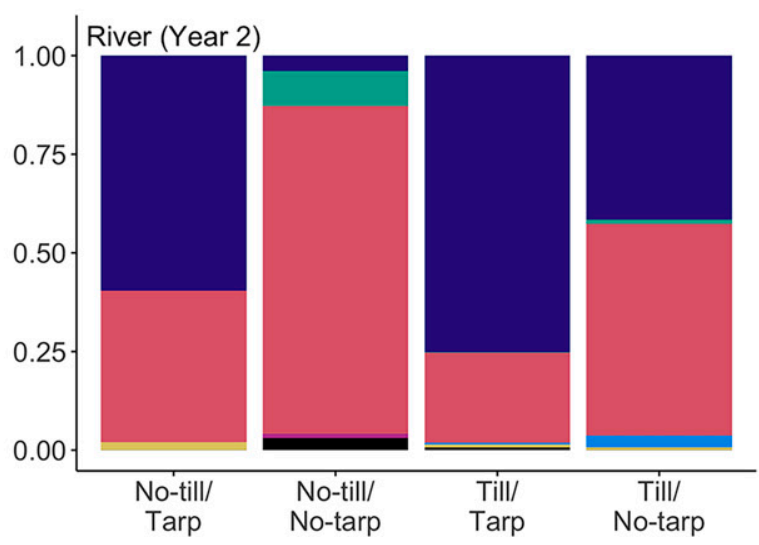

Amaranthus retroflexus $L$

Chenopodium album $L$.

Digitaria sanguinalis (L.) Scop.

Echinochloa crus-galli (L.) P. Beauv.

Portulaca oleracea $L$.

Setaria pumila (Poir.) Roem. \& Schult.

Other ( $<1 \%$ biomass each)

Fig. 5. Relative abundance of weed species after cabbage harvest in unweeded subplots. Year 1 had four replications per field and year 2 had five.

unweeded subplots in till/tarp highlight the impact weeds can have on yields under more standard management practices. The practical implications of this are that tarping may give farmers more flexibility regarding when additional weed control is performed without risking significant yield losses. This is an advantage during the growing season when farmers have multiple demands on their time (Schonbeck, 1999). However, we did not quantify weeding time. Although it is likely

that most farmers using tarps are working on a small scale without mechanization, weeding with cover crop residue requires different tools than weeding bare soil and may affect the amount of labor required.

Tarping was less effective at weed suppression in year 2, which we think was in large part because of low soil moisture when tarps were applied (Fig. 3). We applied tarps immediately after a precipitation event, but the lack of precipitation in May likely led to

Table 4. Shannon diversity index values of weed communities after cabbage harvest. Within a field, means with different letters are significantly different (Tukey's honestly significant difference, $\alpha=0.05$ ). Year 1 fields had four replications and year 2 had five replications.

\begin{tabular}{lcccc}
\hline Field & No-till/Tarp & No-till/No-tarp & Till/Tarp & Till/No-tarp \\
\hline River (year 1) & $0.77 \mathrm{~b}$ & $1.5 \mathrm{a}$ & $1.0 \mathrm{~b}$ & $1.0 \mathrm{~b}$ \\
Road (year 1) & $0.24 \mathrm{c}$ & $1.6 \mathrm{a}$ & $0.90 \mathrm{~b}$ & $0.78 \mathrm{~b}$ \\
River (year 2) & 0.70 & 0.48 & 0.54 & 0.76 \\
\hline
\end{tabular}

a soil water deficit that a single precipitation event was unable to overcome. The efficacy of tarping for weed control relies on adequate soil moisture, which may induce fatal germination of weed seeds (Birthisel and Gallandt, 2019). In dry years, irrigation before tarping may be necessary to make this system most effective. The timing of weeding in the weeded subplots also differed somewhat between the years, but it is an unlikely explanation for the differences observed. Weed management in both years was consistent with what has been identified as necessary to minimize yield losses for cabbage (Kołota and Chohura, 2008; Weaver, 1984).

The absence of a consistent tillage effect on weed biomass at the time of cabbage harvest should not be taken as an indication that tillage had no effect on weed biomass throughout the period of cabbage growth. Tillage is commonly 
used as a weed management technique that gives cash crops an advantage over weeds during their initial growth, but this weed suppression does not last. It is very likely that although tillage suppressed weeds initially (especially in contrast to the no-till/no-tarp treatment), these differences were no longer significant by the time of cabbage harvest, when most weeds in all treatments had reached reproduction. Additionally, it is possible that differences in weed communities between treatments influenced the total weed biomass at the time of cabbage harvest. Disturbance-based events such as tillage can act as strong filters on weed community assembly, leading to dominant species (Booth and Swanton, 2002; Smith and Mortensen, 2017). Higher weed diversity in no-till/no-tarp, in particular, may have served to suppress some dominant, high-biomass weed species, including $A$. retroflexus.

The effects of tarping on weed community composition and diversity indicate that tarping, like tillage, can act as a strong filter on weed community assembly (Birthisel and Gallandt, 2019). Variability in how different weed species respond to levels and quality of cover crop mulch (Pittman et al., 2020; Teasdale and Mohler, 2000) show that cover crop mulch itself has a filtering effect on weed community assembly. Our data suggest that although most weed species present were suppressed by tarping cover crops (i.e., combining the two filters of cover crop mulch and tarps), some were more capable than others of "passing through" these filters, including A. retroflexus. A. retroflexus is one of the most common weeds found on organic farms in Maine and other New England states (Smith et al., 2018). Rylander et al. (2020) found that seeds of a closely related species, A. powelli, had greater survival (i.e., retained viability) under tarps compared with bare soil. These results indicate that farmers should be cautious about selecting for certain weed species and traits when using the notill/tarp system, despite its efficacy at reducing competition from weeds. Approaches to manage weed seed rain may be beneficial in the long-term, even if weeds have only limited impacts on yields (Brown et al., 2019).

\section{Tradeoffs of the system}

Soil moisture. The no-till/tarp system is a promising method of managing soil moisture, but it is multifaceted. Cover crops, the resulting cover crop mulch, and tarps modulate the soil moisture regime for a subsequent cash crop via effects on transpiration, evaporation, and infiltration. In dry years, cover crops can deplete soil moisture and negatively affect availability for a subsequent crop (AlonsoAyuso et al., 2014; Unger and Vigil, 1998). This presents farmers with a difficult decision regarding when to end cover crops if preemptive competition for soil moisture by the cover crop is a concern and irrigation is not available (Alonso-Ayuso et al., 2014). However, early termination limits the quantity of biomass and subsequent mulch, potentially limiting the beneficial effects of moisture conservation later in the season. In wet years, tarps can prevent soils from becoming saturated because they exclude precipitation and maintain soil moisture at relatively constant levels (Fig. 3). This increases flexibility around the timing of field work. Effects of the no-till/tarp system will likely be very different in dry vs. wet years and dependent on when major precipitation events occur (i.e., during cover crop growth, tarping, or cash crop growth).

Opportunity costs. The biggest tradeoff of the no-till/tarp system is captured in the division of thermal units (GDDs) in the season. Thermal units are limited in northern climates and can be used for cover crop production, tarping, or cash crop production. Any activity that takes thermal units away from cash crop production can be viewed as an opportunity cost and must provide additional benefits that compensate for this cost. In this system, cover crop mulch can provide weed suppression, moisture conservation, and nutrients. Additional weed suppression alleviates the labor burden at peak harvest times, but applying and removing tarps require labor at earlier times in the growing season. Moisture conservation, as discussed, is complex but will be increasingly important because of climate change (Kaye and Quemada, 2017).

Although hairy vetch did not provide high biomass (and therefore $\mathrm{N}$ ) in this experiment, the use of legume cover crops, especially in soils with high phosphorus (P) levels, will be increasingly valuable as more states move to regulate P applications (Coale et al., 2002; Kogelmann et al., 2004). The use of hairy vetch has allowed organic farmers to use lower rates of manure-based fertilizer, thereby limiting excessive $P$ accumulation in the mid-Atlantic states (Ackroyd et al., 2019). Greater allocation of thermal units to cover crop production would allow for more hairy vetch biomass production.

Further refinements of the no-till/tarp system include developing thermal models for cover crop growth, tarping period, and cash crop growth to maximize the benefits and minimize the costs with respect to thermal units. There are thermal models for some cover crops (Mirsky et al., 2009; Teasdale et al., 2004; Thapa et al., 2018) and weeds (Myers et al., 2004), but this strategy has not been used for tarping, and it has been used only to a limited extent for vegetable crop growth. Currently, many field activities and research are calendarbased, such as planting dates, days to maturity of crops, and tarping durations. A move to thermal models for all components within the cropping system would allow farmers to assess tradeoffs and determine what is most effective in their unique context.

This work investigated overwintering cover crops for cabbage production. However, growing a cover crop, applying a tarp for a period of days to weeks, and then planting a cash crop in the resulting cover crop mulch could be used for other cover and cash cropping sequences as well. Results from this experiment show that tarps make cover crop-based no-till feasible. The production of in situ mulch from cover crops can reduce the reliance on external inputs like compost or purchased mulch. It should be noted that there are drawbacks and concerns with the use of plastic, even when it is reusable, that are related to production, potential pollution during use, and disposal. Advances in biodegradable plastics show promise for increasing the sustainability of this practice (Sintim et al., 2020).

\section{Literature Cited}

Ackroyd, V.J., M.A. Cavigelli, J.T. Spargo, B. Davis, G. Garst, and S.B. Mirsky. 2019. Legume cover crops reduce poultry litter application requirements in organic systems. Agron. J. 111:2361-2369, https://doi.org/10.2134/agronj 2018.09.0622.

Alonso-Ayuso, M., J.L. Gabriel, and M. Quemada. 2014. The kill date as a management tool for cover cropping success. PLoS One 9(10): e109587, https://doi.org/10.1371/journal.pone. 0109587.

Anderson, M.J. 2001. A new method for non-parametric multivariate analysis of variance. Austral Ecol. 26:32-46, https://doi.org/10.1111/ j.1442-9993.2001.01070.pp.x.

Bates, D., M. Mächler, B. Bolker, and S. Walker. 2015. Fitting linear mixed-effects models using lme4. J. Stat. Softw. 67(i01): https://doi.org/ 10.18637/jss.v067.i01

Birthisel, S.K. and E.R. Gallandt. 2019. Trials evaluating solarization and tarping for improved stale seedbed preparation in the northeast USA. Org. Farming 5:52-65, https://doi.org/ 10.12924/of2019.05010052.

Blanco-Canqui, H., T.M. Shaver, J.L. Lindquist, C.A. Shapiro, R.W. Elmore, C.A. Francis, and G.W. Hergert. 2015. Cover crops and ecosystem services: Insights from studies in temperate soils. Agron. J. 107:2449-2474, https://doi.org/ 10.2134/agronj15.0086.

Booth, B.D. and C.J. Swanton. 2002. Assembly theory applied to weed communities. Weed Sci. 50:2-13, https://doi.org/10.1614/0043-1745 (2002)050[0002:AIATAT]2.0.CO;2.

Boyd, N.S., E.B. Brennan, and S. Fennimore. 2006. Stale seedbed techniques for organic vegetable production. Weed Technol. 20:1052-1057, https://doi.org/10.1614/WT-05-109.1.

Boyd, N.S., E.B. Brennan, R.F. Smith, and R. Yokota. 2009. Effect of seeding rate and planting arrangement on rye cover crop and weed growth. Agron. J. 101:47-51, https://doi.org/ 10.2134/agronj2008.0059.

Brainard, D.C., R.E. Peachey, E.R. Haramoto, J.M. Luna, and A. Rangarajan. 2013. Weed ecology and nonchemical management under strip-tillage: Implications for northern US vegetable cropping systems. Weed Technol. 27:218-230, https://doi.org/10.1614/WT-D-12-00068.1.

Brown, B., A.K. Hoshide, and E.R. Gallandt. 2019. An economic comparison of weed management systems used in small-scale organic vegetable production. Org. Agric. 9:53-63, https://doi.org/10.1007/s13165-018-0206-1.

Cassman, K.G. and D.N. Munns. 1980. Nitrogen mineralization as affected by soil moisture, temperature, and depth. Soil Sci. Soc. Amer. J. 44:1233-1237, https://doi.org/10.2136/sssaj1980. 03615995004400060020x.

Coale, F.J., J.T. Sims, and A.B. Leytem. 2002. Accelerated deployment of an agricultural nutrient management tool: The Maryland phosphorus site index. J. Environ. Qual. 31:1471-1476, https://doi.org/10.2134/jeq2002.1471. 
Fortier, J.-M. and M. Bilodeau. 2014. The market gardener: A successful grower's handbook for small-scale organic farming. New Society Publishers, Gabriola Island, BC, Canada.

Halde, C., S. Gagné, A. Charles, and Y. Lawley. 2017. Organic no-till systems in eastern Canada. Rev. Agr. (Piracicaba) 7:36, https://doi. org/10.3390/agriculture7040036.

Hayhoe, K., C.P. Wake, T.G. Huntington, L. Luo, M.D. Schwartz, J. Sheffield, E. Wood, B. Anderson, J. Bradbury, and A. DeGaetano. 2007. Past and future changes in climate and hydrological indicators in the US Northeast. Clim. Dyn. 28:381-407, https://doi.org/10.1007/s00382-0060187-8.

Hefner, M., S. Canali, K. Willekens, P. Lootens, P. Deltour, A. Beeckman, D. Arlotti, K. Tamm, I. Bender, and R. Labouriau. 2020. Termination method and time of agro-ecological service crops influence soil mineral nitrogen, cabbage yield and root growth across five locations in Northern and Western Europe. Eur. J. Agron. 120:126144, https://doi.org/10.1016/j.eja.2020.126144.

Kaye, J.P. and M. Quemada. 2017. Using cover crops to mitigate and adapt to climate change: A review. Agron. Sustain. Dev. 37:4, https:// doi.org/10.1007/s13593-016-0410-x.

Kogelmann, W.J., H.S. Lin, R.B. Bryant, D.B. Beegle, A.M. Wolf, and G.W. Petersen. 2004. A statewide assessment of the impacts of phosphorus-index implementation in Pennsylvania. J. Soil Water Conserv. 59:9-18.

Kołota, E. and P. Chohura. 2008. The effect of the period of weed control and differentiated nitrogen fertilization on yielding of white head cabbage. Acta Sci. Pol. Hortorum Cultus 7:83-89.

Kornecki, T.S. and M.R. Reyes. 2020. Equipment development for small and urban conservation farming systems. Agriculture 10:595, https:// doi.org/10.3390/agriculture10120595.

Leavitt, M.J., C.C. Sheaffer, D.L. Wyse, and D.L. Allan. 2011. Rolled winter rye and hairy vetch cover crops lower weed density but reduce vegetable yields in no-tillage organic production. HortScience 46:387-395, https://doi.org/ 10.21273/HORTSCI.46.3.387.

Lenth, R. 2020. emmeans: Estimated marginal means, aka least-squares means. $\mathrm{R}$ package version 1.6.1.

Lounsbury, N.P., N.D. Warren, S.D. Wolfe, and R.G. Smith. 2020. Investigating tarps to facilitate organic no-till cabbage production with high-residue cover crops. Renew. Agr. Food Syst. 35:227-233, https://doi.org/10.1017/S17 42170518000509.

Lounsbury, N.P. and R.R. Weil. 2015. No-till seeded spinach after winterkilled cover crops in an organic production system. Renew. Agr. Food Syst. 30:473-485, https://doi.org/10.1017/ S1742170514000301.

Lowry, C.J. and D.C. Brainard. 2019. Organic farmer perceptions of reduced tillage: A Michigan farmer survey. Renew. Agr. Food Syst. 34:103-115, https://doi.org/10.1017/S1742170 517000357.

Mays, D. 2020. The no-till organic vegetable farm: how to start and run a profitable market garden that builds health in soil, crops, and communities. Storey Publishing, North Adams, MA.

Mefferd, A. 2019. The organic no-till farming revolution: high-production methods for smallscale farmers. New Society Publishers, Gabrioloa Island, BC, Canada.

Mirsky, S.B., V.J. Ackroyd, S. Cordeau, W.S. Curran, M. Hashemi, S.C. Reberg-Horton, M.R. Ryan, and J.T. Spargo. 2017. Hairy vetch biomass across the Eastern United States: Effects of latitude, seeding rate and date, and termination timing. Agron. J. 109:1510-1519, https://doi.org/ 10.2134/agronj2016.09.0556.

Mirsky, S.B., W.S. Curran, D.A. Mortensen, M.R. Ryan, and D.L. Shumway. 2009. Control of cereal rye with a roller/crimper as influenced by cover crop phenology. Agron. J. 101:1589-1596, https://doi.org/10.2134/agronj2009.0130.

Mirsky, S.B., W.S. Curran, D.M. Mortensen, M.R Ryan, and D.L. Shumway. 2011. Timing of cover-crop management effects on weed suppression in no-till planted soybean using a roller-crimper. Weed Sci. 59:380-389, https:// doi.org/10.1614/WS-D-10-00101.1.

Mirsky, S.B., M.R. Ryan, J.R. Teasdale, W.S. Curran, C.S. Reberg-Horton, J.T. Spargo, M.S. Wells, C.L. Keene, and J.W. Moyer. 2013. Overcoming weed management challenges in cover crop-based organic rotational no-till soybean production in the eastern United States. Weed Technol. 27:193-203, https://doi.org/ 10.1614/WT-D-12-00078.1.

Mochizuki, M.J., A. Rangarajan, R.R. Bellinder, T. Björkman, and H.M. van Es. 2007. Overcoming compaction limitations on cabbage growth and yield in the transition to reduced tillage. HortScience 42:1690-1694, https://doi.org/ 10.21273/HORTSCI.42.7.1690.

Mochizuki, M.J., A. Rangarajan, R.R. Bellinder, H.M. van Es, and T. Björkman. 2008. Rye mulch management affects short-term indicators of soil quality in the transition to conservation tillage for cabbage. HortScience 43:862-867, https:// doi.org/10.21273/HORTSCI.43.3.862.

Myers, M.W., W.S. Curran, M.J. VanGessel, D.D. Calvin, D.A. Mortensen, B.A. Majek, H.D Karsten, and G.W. Roth. 2004. Predicting weed emergence for eight annual species in the northeastern United States. Weed Sci. 52:913-919, https://doi.org/10.1614/WS-04-025R.

O'Connell, S., J.M. Grossman, G.D. Hoyt, W. Shi, S. Bowen, D.C. Marticorena, K.L. Fager, and N.G. Creamer. 2015. A survey of cover crop practices and perceptions of sustainable farmers in North Carolina and the surrounding region. Renew. Agr. Food Syst. 30:550-562, https:// doi.org/10.1017/S1742170514000398.

Oksanen, J., F.G. Blanchet, R. Kindt, P. Legendre, P.R. Minchin, R.B. O'Hara, G.L. Simpson, P. Solymos, M.H.H. Stevens, and H. Wagner. 2015. vegan: Community ecology package. 2019. R Package Version 2.

Pittman, K., J. Barney, and M. Flessner. 2020 Cover crop residue components and their effect on summer annual weed suppression in corn and soybean. Weed Sci. 68:301-310, https:// doi.org/10.1017/wsc.2020.16.

R Core Team. 2020. R: A language and environment for statistical computing. R Foundation for Statistical Computing, Vienna, Austria.

Reberg-Horton, S.C., J.M. Grossman, T.S. Kornecki, A.D. Meijer, A.J. Price, G.T. Place, and T.M. Webster. 2012. Utilizing cover crop mulches to reduce tillage in organic systems in the southeastern USA. Renew. Agr. Food Syst. 27:41-48, https://doi.org/10.1017/S1742170511000469.

Rylander, H., A. Rangarajan, R.M. Maher, M.G. Hutton, N.W. Rowley, M.T. McGrath, and Z.F. Sexton. 2020. Black plastic tarps advance organic reduced tillage I: Impact on soils, weed seed survival, and crop residue. HortScience 55:819-825, https://doi.org/10.21273/HORTSCI 14792-19.

Schmider, E., M. Ziegler, E. Danay, L. Beyer, and M. Bühner. 2010. Is it really robust? Reinvestigating the robustness of ANOVA against violations of the normal distribution assumption. Methodology 6:146-151, https://doi.org/10.1027/ 1614-2241/a000016.
Schonbeck, M.W. 1999. Weed suppression and labor costs associated with organic, plastic, and paper mulches in small-scale vegetable production. J. Sustain. Agr. 13:13-33, https://doi.org/ 10.1300/J064v13n02_04.

Sintim, H.Y., A.I. Bary, D.G. Hayes, L.C. Wadsworth, M.B. Anunciado, M.E. English, S. Bandopadhyay, S.M. Schaeffer, J.M. DeBruyn, and C.A. Miles. 2020. In situ degradation of biodegradable plastic mulch films in compost and agricultural soils. Sci. Total Environ. 727:138668, https://doi.org/10.1016/j.scitotenv.2020.138668.

Small, G., P. Shrestha, G.S. Metson, K. Polsky, I. Jimenez, and A. Kay. 2019. Excess phosphorus from compost applications in urban gardens creates potential pollution hotspots. Environ. Res. Commun. 1:91007, https://doi.org/10.1088/2515$7620 / a b 3 b 8 c$.

Smith, R.G., S.K. Birthisel, S.C. Bosworth, B. Brown, T.M. Davis, E.R. Gallandt, A. Hazelrigg, E. Venturini, and N.D. Warren. 2018. Environmental correlates with germinable weed seedbanks on organic farms across northern New England. Weed Sci. 66:78-93, https:// doi.org/10.1017/wsc.2017.40.

Smith, R.G. and D.A. Mortensen. 2017. A disturbance-based framework for understanding weed community assembly in agroecosystems, p. 127-153. In: A. Wezel (ed.). Challenges and opportunities for agroecological weed management. Agroecological practices for sustainable agriculture: Principles, applications, and making the transition. ISARA-Lyon, France.

Teasdale, J.R. and C.L. Mohler. 1993. Light transmittance, soil temperature, and soil moisture under residue of hairy vetch and rye. Agron. J. 85:673-680, https://doi.org/10.2134/agronj1993. 00021962008500030029x.

Teasdale, J.R. and C.L. Mohler. 2000. The quantitative relationship between weed emergence and the physical properties of mulches. Weed Sci. 48:385-392, https://doi.org/10.1614/0043-1745 (2000)048[0385:TQRBWE]2.0.CO;2.

Teasdale, J.R., T.E. Devine, J.A. Mosjidis, R.R. Bellinder, and C.E. Beste. 2004. Growth and development of hairy vetch cultivars in the northeastern United States as influenced by planting and harvesting date. Agron. J. 96:1266-1271, https://doi.org/10.2134/agronj2004.1266.

Thapa, R., H. Poffenbarger, K.L. Tully, V.J. Ackroyd, M. Kramer, and S.B. Mirsky. 2018 Biomass production and nitrogen accumulation by hairy vetch-cereal rye mixtures: A metaanalysis. Agron. J. 110:1197-1208, https://doi. org/10.2134/agronj2017.09.0544.

Unger, P.W. and M.F. Vigil. 1998. Cover crop effects on soil water relationships. J. Soil Water Conserv. 53:200-207.

Wallace, J.M., A. Williams, J.A. Liebert, V.J. Ackroyd, R.A. Vann, W.S. Curran, C.L. Keene, M.J. VanGessel, M.R. Ryan, and S.B. Mirsky. 2017. Cover crop-based, organic rotational notill corn and soybean production systems in the mid-Atlantic United States. Agriculture 7:34, https://doi.org/10.3390/agriculture7040034.

Weaver, S.E. 1984. Critical period of weed competition in three vegetable crops in relation to management practices. Weed Res. 24:317-325, https://doi.org/10.1111/j.1365-3180.1984.tb00 593.x.

Wickham, H. 2016. ggplot2: Elegant graphics for data analysis. Springer-Verlag, New York, NY.

Wolfe, D.W., D.T. Topoleski, N.A. Gundersheim, and B.A. Ingall. 1995. Growth and yield sensitivity of four vegetable crops to soil compaction. J. Amer. Soc. Hort. Sci. 120:956-963, https://doi. org/10.21273/JASHS.120.6.956. 